\title{
Elevated carbohydrate antigen 19-9 in patients with true (epithelial) splenic cysts - Rare or undiscovered?
}

\author{
Michal Soudack MD ${ }^{1}$, Alon Ben-Nun MD PhD², Chaim Toledano MD 3
}

\begin{abstract}
M Soudack, A Ben-Nun, C Toledano. Elevated carbohydrate antigen 19-9 in patients with true (epithelial) splenic cysts Rare or undiscovered? Can J Gastroenterol 2001;15(2):125126. Carbohydrate antigen $19-9$ is a well known marker for pancreatic adenocarcinoma. However, its limitation is its nonspecificity, because elevated levels may be encountered in other gastrointestinal disorders, both benign and malignant. The following case is a patient with a true (epithelial) splenic cyst with elevated serum levels of carbohydrate antigen 19-9.
\end{abstract}

Key Words: CA 19-9; Carbohydrate antigen 19-9; Splenic cyst
Concentration élevée d'antigènes carbohydrate 19-9 chez les patients atteints de véritables kystes spléniques (épithéliaux) : fait rare ou découverte fortuite?

RÉSUMÉ : L'antigène carbohydrate 19-9 est un marqueur bien connu de l'adénocarcinome pancréatique. Toutefois, sa limite réside dans le fait qu'il n'a aucune spécificité étant donné que des concentrations élevées peuvent être associées à d'autres troubles gastro-intestinaux, tant bénins que malins. Voici le cas d'une patiente atteinte d'un véritable kyste splénique (épithélial) qui présente une concentration sérique élevée d'antigènes carbohydrate 19-9.

\section{CASE PRESENTATION}

A 24-year-old woman had intermittent, vague abdominal pain for eight months. Her past health history was unremarkable. Ultrasonography and a computed tomography scan of the abdomen revealed a large, well defined cyst between the spleen and the tail of the pancreas. The serum concentration of carbohydrate antigen (CA) 19-9 was $1200 \mathrm{U} / \mathrm{mL}$ (normal is less than $37 \mathrm{U} / \mathrm{mL}$ ). At laparotomy, a large splenic cyst was disclosed and splenectomy was performed. Histology showed that the lesion was a benign epithelial splenic cyst.

\section{DISCUSSION}

True splenic cysts, by definition, have a cellular lining (as opposed to false or pseudocysts) and comprise approximately $10 \%$ of all benign, nonparasitic splenic cysts. They occur most commonly in young females. Although often asymptomatic, they may cause nonspecific abdominal symptoms. The clinical importance of true splenic cysts lies in their potential, at times fatal, to rupture or to become infected; therefore, the preferred treatment is surgical removal. True cysts are divided into epithelial and mesothelial subgroups depending on their cellular lining. There are two main hypotheses regarding histogenesis: first, the embryonic inclusion of epithelial cells from adjacent organs, and second, the post-traumatic invagination of mesothelial cells. There is also evidence that the epithelial subtype is a result of squamous metaplasia of the mesothelial lining.

CA 19-9 is considered the most useful blood test for diagnosing and managing patients with carcinoma of the pancreas. The radioimmunometric assay has a sensitivity of approximately $88 \%$ and a specificity of $90 \%$. Although the

Departments of ${ }^{1}$ Diagnostic Radiology, ${ }^{2}$ Thoracic Surgery and ${ }^{3}$ General Surgery, Rambam Medical Center, Bat Galim, Haifa, Israel Correspondence: Dr Michal Soudack, Department of Diagnostic Radiology, Rambam Medical Center, Bat Galim, Haifa, Israel.

Telephone +972-4-8542664, fax+972-4-8542690, e-mail mangn@netmedia.net.il

Received for publication October 13, 1999. Accepted November 29, 1999 
serum level of CA 19-9 may be elevated in patients with other gastrointestinal adenocarcinomas and benign disorders such as pancreatitis, cholangitis, cholelithiasis and hepatitis, CA 19-9 is most prominent in pancreatic adenocarcinoma. CA 19-9 is also produced by normal human epithelial cells of the pancreas, biliary tract, salivary glands, colon, endometrium and bronchial glands.

In our search of the medical literature, four other cases of true splenic cysts accompanied by elevated blood levels of CA 19-9 were found (1-4). Because the serum levels of this marker are unknown in other unpublished cases of true epithelial splenic cysts, we cannot determine whether elevated CA 19-9 levels are a rule or an exception to the rule for true splenic cysts. On the basis of previous findings and the present report, we suggest the following: CA 19-9 should be measured in all cases of splenic cysts to determine whether elevated levels are characteristic or sporadic; true epithelial cysts should be added to the list of disorders accompanied by elevated levels of this marker; and serum CA 19-9 tests should be employed cautiously when differentiating cystic pancreatic adenocarcinoma from other left upper abdominal cystic masses.

\section{REFERENCES}

1. Walz MK, Metz KA, Sastry M, et al. Benign mesothelial splenic cyst may cause high serum concentration of CA 19-9. Eur J Surg 1994:160:389-91.

2. Tereda T, Yasoshima M, Yoshimitsu Y, et al. Carbohydrate antigen 19-9 producing giant epithelial cyst of the spleen in a young woman. J Clin Gastroenterol 1994;18:57-61.

3. Fujita M, Morita T, Okushiba T, et al. A case of wandering giant splenic cyst with high level of serum CA 19-9. J Jpn Soc Clin Surg 1993;54;2660-5.

4. Yoshikane H, Suzuki T, Yoshioka N, et al. Giant splenic cyst with high serum concentration of CA 19-9. Scand J Gastroenterol 1996;31:524-6. 


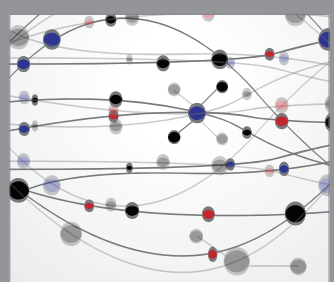

The Scientific World Journal
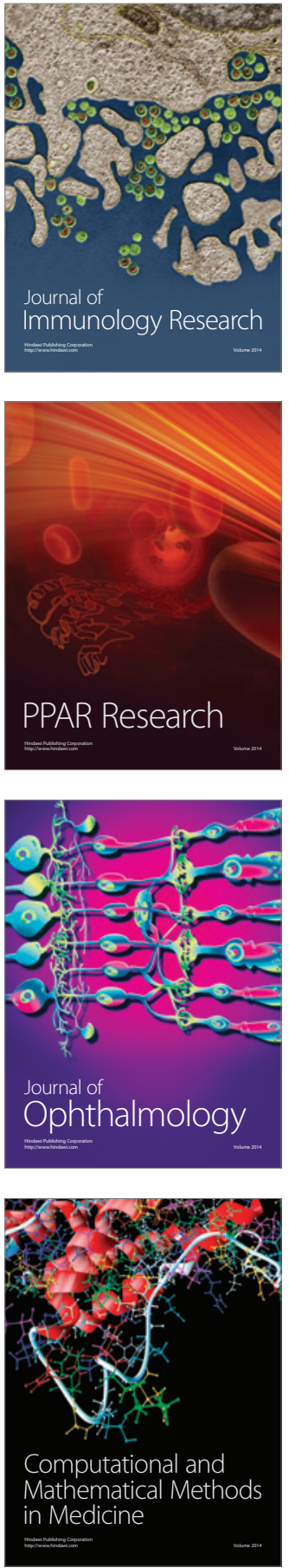

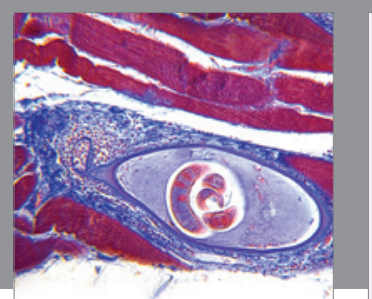

Gastroenterology Research and Practice

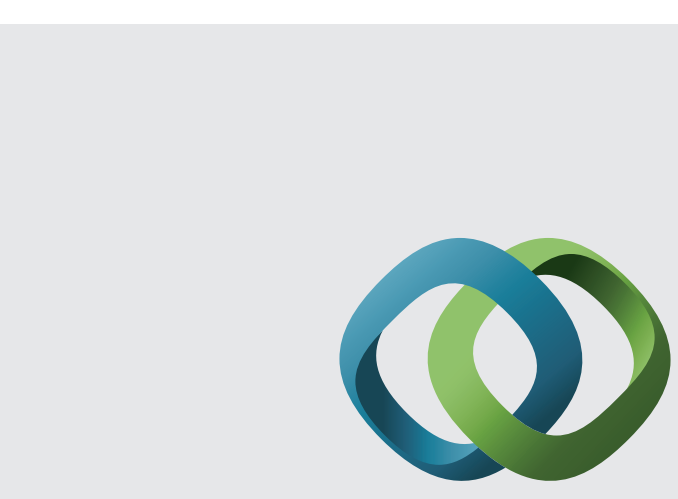

\section{Hindawi}

Submit your manuscripts at

http://www.hindawi.com
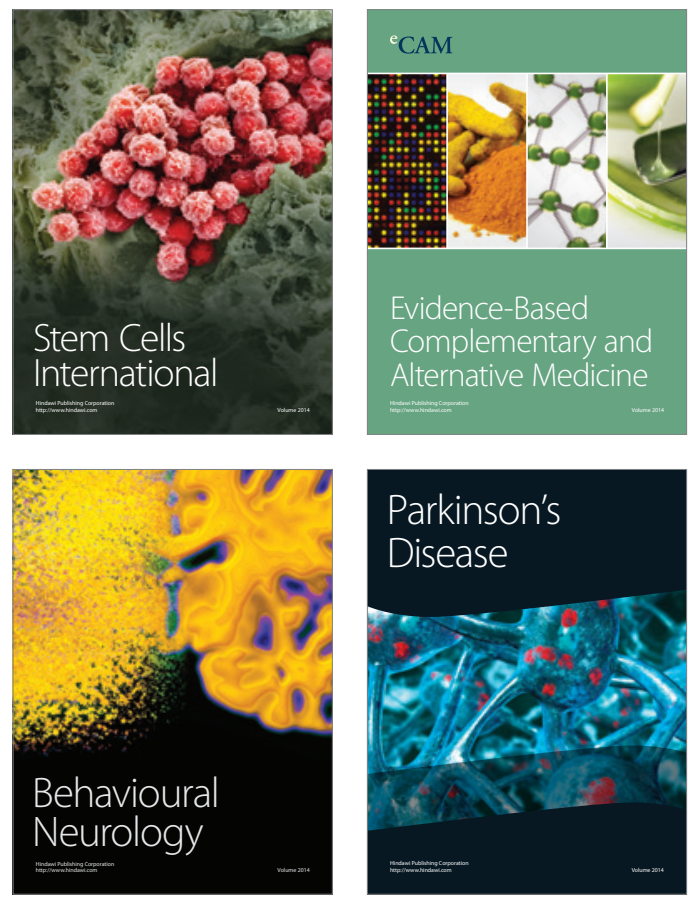
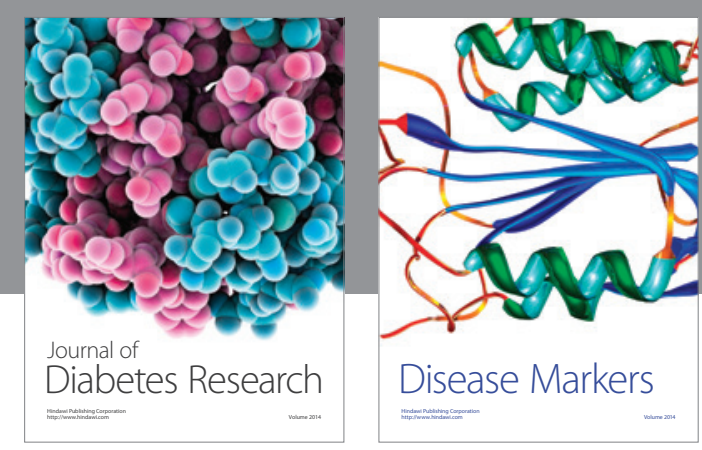

Disease Markers
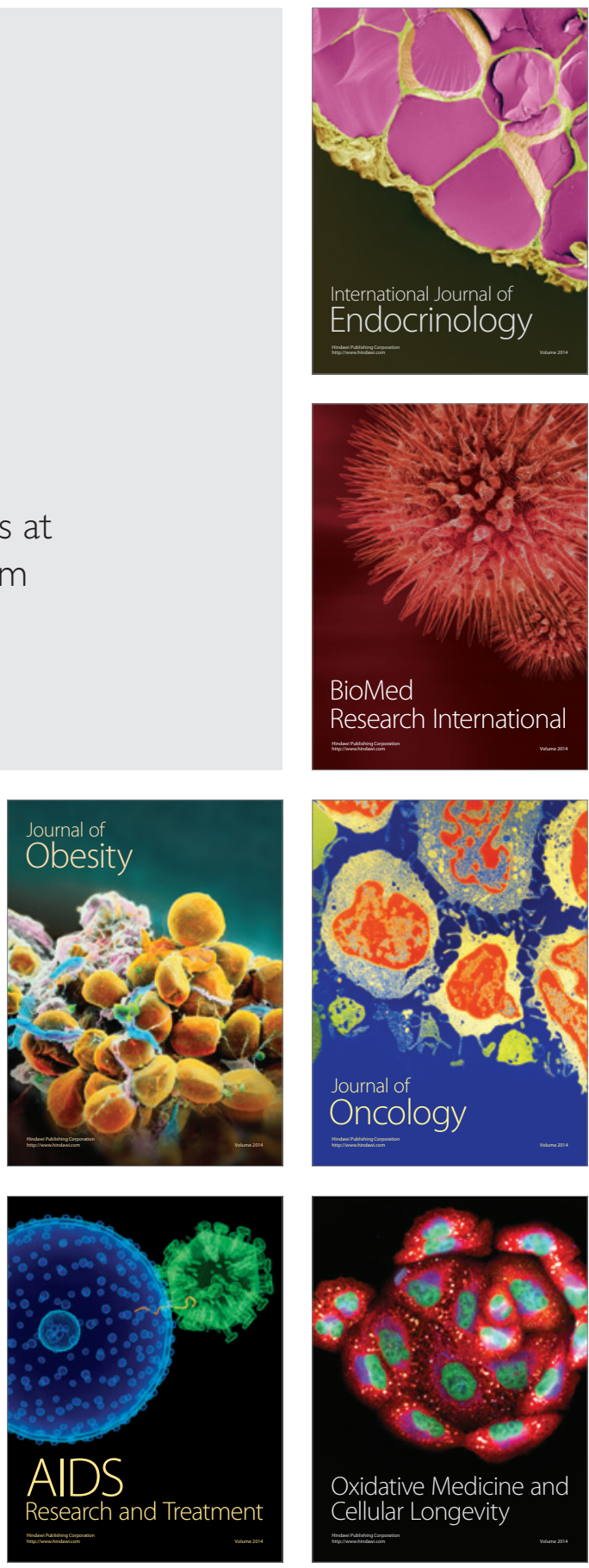